\title{
PENGARUH PENAMBAHAN KARAGENAN TERHADAP KARAKTERISTIK FRUIT LEATHER KULIT BUAH NAGA MERAH (Hylocereus polyrhizus)
}

\author{
Heni Monaria Tondang ${ }^{1}$, I Gusti Ayu Ekawati ${ }^{2}$, A.A.I. Sri Wiadnyani ${ }^{2}$ \\ ${ }^{1}$ Mahasiswa Jurusan Ilmu dan Teknologi Pangan, Fakultas Teknologi Pertanian, Universitas Udayana \\ ${ }^{2}$ Dosen Jurusan Ilmu dan Teknologi Pangan, Fakultas Teknologi Pertanian, Universitas Udayana \\ Email : Monaria.heni@yahoo.com
}

\begin{abstract}
This study aims to determine of various carrageenan concentrations that affect the characteristics from fruit leather of red dragon fruit peel and find out the exact carrageenan concentration to produce fruit leather of red dragon fruit peel with the best characteristics. The experiment used Completely Randomized Design (RAL) with 5 levels of carrageenan concentration treatment ie $0 ; 0.3 \% ; 0.6 \% ; 0.9 \%$ $; 1.2 \%$ of $100 \mathrm{~g}$ of red dragon fruit peel. Each treatment was repeated 3 times to obtain 15 units of experiment. The resulting data is then analyzed using anova, and if there is significant effect of the treatment on the observed parameters, then it will be followed by Duncan test.The results showed that the addition of carrageenan treatment had a significant effect on the water content, crude fiber, tensile strength, color, texture. The best treatment was obtained at the treatment of 1,2\% of carrageenan with water content of $10.41 \%$, crude fiber $7.02 \%$, antioxidant capacity $0.74 \%$, total sugar $54.24 \%$, tensile strength 2.19 MPa, Sensory evaluation with scores and hedonic test is color very red and liked, texture is chewy and rather liked, aroma and flavor rather liked, overall acceptance liked.
\end{abstract}

Keywords: Fruit leather, Red dragon fruit peel, Carrageenan

\section{PENDAHULUAN}

Buah naga mulai masuk di Indonesia pada tahun 2003, buah naga tergolong dalam keluarga Cactaceae atau kaktus yang berasal dari negaranegara Amerika Latin (Chile, Argentina, Peru, Mexico). Setiap tahun, produksi buah naga meningkat, begitu juga dengan import buah naga ke Indonesia. Berdasarkan catatan dari eksportir buah di Indonesia, buah naga ini masuk ke tanah air mencapai antara $200-400$ ton/tahun asal Thailand dan Vietnam (Anonim., 2013). Masyarakat menyukai buah naga karena mengandung manfaat bagi kesehatan. Menurut Saati (2009), kulit buah naga berjumlah 30-35 \% dari berat buahnya dan seringkali hanya dibuang sebagai sampah. Hasil penelitian menunjukkan kulit buah naga mengandung antioksidan dan juga dapat menurunkan kadar kolesterol (Kanner dkk., 2001).

Menurut penelitian yang dilakukan oleh Saneto (2010), kulit buah naga mengandung serat yang cukup tinggi yang dapat dikembangkan lebih optimal sebagai sumber serat pangan untuk makanan. Keunggulan kulit buah naga merah adalah kaya akan polifenol dan sumber antioksidan dan tidak mengandung toksik (Wahyuni, 2011). Selain itu menurut Rebecca (2010) dalam Hajru (2013) kulit buah naga daging merah memiliki seyawa aktif 
betasianin yang dapat mengikat radikal bebas dan dikatakan sebagai sumber antioksidan. Selain itu, kulit buah naga pun memiliki warna alami yang baik sehingga tidak diperlukan penambahan pewarna makanan apabila diaplikasikan pada produk pangan. Mempertimbangkan manfaat kulit buah naga merah tersebut dipilih sebagai bahan baku dalam pembuatan fruit leather.

Fruit leather adalah jenis makanan yang berasal dari daging buah yang telah dihancurkan dan dikeringkan. Produk ini berbentuk lembaran tipis seperti halnya kulit buah, dengan tekstur yang plastis dan kenyal, rasanya manis tetapi masih memiliki ciri rasa khas buah yang digunakan, dan kenampakannya seperti kulit. Fruit leather mempunyai keuntungan tertentu yaitu masa simpan yang cukup lama, mudah diproduksi, dan nutrisi yang terkandung didalamnya tidak banyak berubah (Kwartiningsih dan Mulyati, 2005). Fruit leather yang baik menurut Nurlaely dalam Murdinah (2010) adalah memiliki kandungan air sebesar $10-15 \%$, nilai $a W$ kurang dari 0,7 .

Menurut Historiarsih (2010), masalah yang sering timbul pada fruit leather adalah plastisitasnya yang kurang baik. Maka dalam penelitian ini, dipergunakan bahan tambahan yang berfungsi sebagai gelling agent yang dapat memperbaiki tekstur fruit leather yaitu karagenan. Jika dibandingkan dengan hidrokoloid lain misalnya gum arab, karagenan lebih ekonomis dari segi harga dan lebih stabil dalam mengimobilisasi air pada konsentrasi yang lebih rendah dari gum arab. Gum arab mampu mengikat air lebih stabil pada konsentrasi di atas 1\%. Kappa karagenan merupakan pembentuk gel terbaik dibandingkan iota dan lambda karagenan. Pemilihan kappa karagenan sebagai hidrokoloid juga mampu meningkatkan kadar serat dalam fruit leather (Murdinah, 2010). Berdasarkan beberapa hal diatas, perlu dilakukan penelitian mengenai fruit leather kulit buah naga dengan penambahan karagenan.

\section{BAHAN DAN METODE}

\section{Tempat dan Waktu Penelitian}

Penelitian ini dilaksanakan di laboratorium Pengolahan Pangan, Analisis Pangan serta Rekayasa Proses dan Pengendalian Mutu Fakultas Teknologi Pertanian, Universitas Udayana dan Laboratorium Fakultas Teknologi Pertanian, Universitas Gadjah Mada. Penelitian ini dilaksanakan pada bulan Maret sampai dengan bulan April 2017.

\section{Alat dan Bahan}

Alat yang digunakan dalam proses pembuatan fruit leather kulit buah naga merah adalah oven, sendok, pisau, timbangan analitik (Shimadzu), baskom, panci, spatula plastik, timbangan dan blender (Philips). alat untuk analisa, antara lain krus porselen, penjepit cawan, loyang, stopwatch, kompor listrik, desikator, oven (Memmert), tabung reaksi, erlenmeyer, kertas saring, corong, labu takar, gelas ukur, pipet volume, spektrofotometer 
(Genesys 10S UV-Vis), Universal Testing Instrumen ( Zwick/ Z0.5).

Bahan yang digunakan adalah kulit buah naga merah (Hylocereus polyrhizus) yang diperoleh dari seminyak, Bali. Karagenan jenis kappa yang diperoleh dari CV. Nurajaya Surabaya dan asam sitrat diperoleh dari UD. Fenny Denpasar, gula "gulaku", $\mathrm{NaOH} 0.313 \mathrm{~N}$, $\mathrm{H}_{2} \mathrm{SO}_{4} \quad 0.255 \mathrm{~N}$, Metanol dan larutan 1,1diphenyl-2-picrylhydrazyl (DPPH) $0.004 \%$, aquades, alkohol, larutan $\mathrm{I}_{2}$, Amilum 1\%.

\section{Rancangan Penelitian}

Rancangan yang digunakan pada penelitian ini adalah Rancangan Acak Lengkap (RAL) dengan perlakuan konsentrasi karagenan dengan 5 taraf yaitu:

$\mathrm{P} 0=$ tanpa penambahan karagenan

$\mathrm{P} 1=$ penambahan $0,3 \%$ Karagenan

$\mathrm{P} 2=$ penambahan $0,6 \%$ Karagenan

P3 = penambahan $0,9 \%$ Karagenan

$\mathrm{P} 4=$ penambahan $1,2 \%$ Karagenan

Penambahan konsentrasi karagenan berdasarkan pada berat kulit buah naga yang digunakan. Masing-masing perlakuan diulang sebanyak 3 kali sehingga diperoleh 15 unit percobaan. Data yang dihasilkan kemudian dianalisis dengan analisis ragam pada program SPSS 17 dan apabila terdapat pengaruh perlakuan terhadap variabel, maka dilanjutkan dengan uji Duncan (Harsojuwono dkk., 2011).

\section{Variabel Yang Diamati}

Variabel yang diamati dalam penelitian ini adalah analisis kadar air dengan metode oven
(Sudarmaji dkk., 1997), kadar serat kasar dilakukan dengan metode hidrolisis asam dan basa (Sudarmadji dkk., 1997), kapasitas antioksidan dengan metode DPPH (Yun, 2001), total gula dengan metode Nelson-Somogi (Sudarmadji dkk., 1997), uji tensile strength (kuat tarik) dilaksanakan di Laboratorium Rekayasa Proses Pengolahan, Universitas Gadjah Mada dengan Universal Testing Instrument, serta uji sifat sensoris menggunakan uji skor meliputi warna dan tekstur, serta uji hedonik (kesukaan) terhadap warna, aroma, rasa, tekstur dan penerimaan keseluruhan (Soekarto, 1985).

\section{Pelaksanaan Penelitian}

Persiapan bahan-bahan yang digunakan dalam pembuatan fruit leather kulit buah naga merah yaitu kulit buah naga, karagenan, gula pasir, asam sitrat dan air. Bahan yang digunakan kemudian ditimbang sesuai dengan formulasinya. Formulasi fruit leather kulit buah naga merah dapat dilihat pada Tabel 1.

Pembuatan fruit leather Kulit Buah Naga merujuk pada penelitian yang telah dilakukan oleh Ciptaning, dkk (2014) dan formulasinya dapat dilihat pada Tabel 1. Pembuatan fruit lether kulit buah naga dimulai dengan pencucian kulit buah naga. Kulit buah naga ditimbang sebanyak $100 \mathrm{~g}$, ditambahkan air sebanyak $50 \mathrm{ml}$ dan gula $30 \mathrm{~g}$, kemudian diblender hingga halus, selanjutnya dipanaskan pada suhu $80^{\circ} \mathrm{C}$ selama 2 menit, sehingga diperoleh puree kulit buah naga. Puree kulit buah naga ditambahkan asam 
sitrat sebanyak 0,2 g dan karagenan sesuai perlakuan $(0 \%, 0,3 \%, 0,6 \%, 0,9 \%, \quad 1,2 \%)$ berdasarkan berat kulit buah naga yang digunakan. Setelah itu dicetak dalam Loyang berukuran $15 \times 10 \times 3 \mathrm{~cm}$ yang telah dilapisi kertas roti, dengan ketebalan puree pada loyang $\pm 1 \mathrm{~cm}$, selanjutnya dimasukan kedalam oven untuk proses pengeringan selama 8 jam dengan suhu $60^{\circ} \mathrm{C}$. Selanjutnya masing-masing fruit leather dianalisis sifat fisik dan kimia yang meliputi kadar air, kadar serat kasar, kapasitas antioksidan, total gula, uji tensile strength (kuat tarik) dan uji sensoris meliputi warna, tekstur, rasa, aroma, dan penerimaan keseluruhan.

Tabel 1. Formula fruit lether per $100 \mathrm{~g}$ bubur buah kulit buah naga

\begin{tabular}{|l|c|c|c|c|c|}
\hline \multirow{2}{*}{\multicolumn{2}{|c|}{ Komposisi }} & \multicolumn{5}{c|}{ Perlakuan } \\
\cline { 2 - 6 } & P1 & P2 & P3 & P4 & P5 \\
\hline Bubur buah kulit buah naga (\%) & 100 & 100 & 100 & 100 & 100 \\
\hline Air (\%) & 50 & 50 & 50 & 50 & 50 \\
\hline Gula pasir (\%) & 30 & 30 & 30 & 30 & 30 \\
\hline Asam sitrat (\%) & 0,2 & 0,2 & 0,2 & 0,2 & 0,2 \\
\hline Karagenan (\%) & 0 & 0,3 & 0,6 & 0,9 & 1,2 \\
\hline
\end{tabular}

Keterangan: Presentase berdasarkan berat bubur kulit buah naga

\section{HASIL DAN PEMBAHASAN}

Hasil pengamatan dari nilai rata-rata kadar air, serat kasar, kapasitas antioksidan, total gula dan tensile strength dari fruit leather kulit buah naga merah dengan perlakuan penambahan karagenan, dapat dilihat pada Tabel 2.

\section{Kadar Air}

Berdasarkan hasil analisis ragam menunjukan bahwa penambahan karagenan pada fruit leather kulit buah naga merah berpengaruh sangat nyata $(\mathrm{P}<0,01)$ terhadap kadar air fruit leather. Nilai rata-rata kadar air fruit leaher dapat dilihat pada Tabel 2. Tabel 2 Menunjukan bahwa nilai rata-rata kadar air fruit leather berkisar antara 10,41\% - 13,29\%. Nilai rata-rata kadar air tertinggi terdapat pada penambahan karagenan 0 g (P0) yaitu sebesar 13,29\%, sedangkan nilai rata-rata kadar air terendah terdapat pada penambahan karagenan 1,2\% (P4) yaitu sebesar $10,41 \%$ tidak berbeda dengan penambahan karagenan $0,6 \%(\mathrm{P} 2)$ dan $0,9 \%$ (P3).

Hal ini menunjukan semakin banyak penambahan karagenan kadar air pada fruit leather semakin menurun. Pada penelitian ini penambahan karagenan berfungsi sebagai gelling agent. Menurut Fardiaz (1989), pembentukan gel adalah suatu fenomena penggabungan atau pengikatan silang rantai-rantai polimer sehingga 
terbentuk suatu jala tiga dimensi bersambungan, selanjutnya jala ini menangkap atau mengimobilisasikan air di dalamnya dan membentuk struktur yang kuat dan kaku. Salah satu sifat karagenan adalah mampu mengimobilisasikan air. Semakin tinggi konsentrasi karagenan yang ditambahkan pada fruit leather kulit buah naga menyebabkan jumlah air bebas dan air teradsorbsi yang ada dalam bahan semakin menurun. Kadar air yang tercantum pada SNI No.1718 tentang manisan kering adalah maksimal 25\%, maka semua perlakuan pada produk fruit leather kulit buah naga ini sudah memenuhi SNI yang ditentukan.

Tabel 2. Nilai Rata-rata Kadar Air, Serat Kasar, Kapasitas Antioksidan, Total Gula, dan Tensile Strengthfruit leather Kulit Buah Naga

\begin{tabular}{cccccc}
\hline Perlakuan & Kadar air (\%) & $\begin{array}{c}\text { Kadar Serat } \\
\text { kasar (\%) }\end{array}$ & $\begin{array}{c}\text { Kapasitas } \\
\text { antioksidan } \\
(\%)\end{array}$ & Total Gula (\%) & $\begin{array}{c}\text { Tensile strength } \\
(\mathrm{MPa})\end{array}$ \\
\hline P0 & $13,29 \pm 0,74 \mathrm{c}$ & $4,69 \pm 0,24 \mathrm{a}$ & $0,75 \mathrm{a} \pm 0,04 \mathrm{a}$ & $50,07 \pm 0,59 \mathrm{a}$ & $0,62 \pm 0,09 \mathrm{a}$ \\
P1 & $11,79 \pm 0,09 \mathrm{~b}$ & $6,02 \pm 0,45 \mathrm{~b}$ & $0,72 \pm 0,09 \mathrm{a}$ & $52,35 \pm 1,80 \mathrm{a}$ & $1,15 \pm 0,22 \mathrm{~b}$ \\
P2 & $11,25 \pm 0,22 \mathrm{ab}$ & $6,05 \pm 0,32 \mathrm{~b}$ & $0,70 \pm 0,06 \mathrm{a}$ & $52,94 \pm 3,64 \mathrm{a}$ & $1,48 \pm 0,24 \mathrm{~b}$ \\
P3 & $11,11 \pm 0,67 \mathrm{ab}$ & $6,65 \pm 0,51 \mathrm{bc}$ & $0,72 \pm 0,04 \mathrm{a}$ & $53,55 \pm 3,33 \mathrm{a}$ & $1,50 \pm 0,15 \mathrm{~b}$ \\
P4 & $10,41 \pm 0,09 \mathrm{a}$ & $7,02 \pm 0,06 \mathrm{c}$ & $0,74 \pm 0,04 \mathrm{a}$ & $54,24 \pm 0,6 \mathrm{a}$ & $2,18 \pm 0,51 \mathrm{c}$ \\
\hline
\end{tabular}

Keterangan : Nilai Rata-rata yang diikuti oleh huruf yang berbeda pada kolom yang sama menunjukan perbedaan yang sangat nyata $(\mathrm{P}<0,01)$.

\section{Serat Kasar}

Berdasarkan hasil analisis ragam menunjukan bahwa penambahan karagenan pada fruit leather kulit buah naga merah berpengaruh sangat nyata $(\mathrm{P}<0,01)$ terhadap kadar serat kasar fruit leather. Nilai rata-rata kadar serat fruit leaher dapat dilihat pada Tabel 2. Tabel 2 Menunjukan bahwa nilai rata-rata kadar serat fruit leather berkisar antara 4,69\% - 7,03\%. Nilai rata-rata kadar serat tertinggi terdapat pada penambahan karagenan 1,2 g (P4) yaitu sebesar $7,03 \%$ tidak berbeda dengan penambahan karagenan $0,9 \mathrm{~g}(\mathrm{P} 3)$, sedangkan nilai rata-rata kadar serat terendah terdapat pada penambahan karagenan 0 g (P0) yaitu sebesar 4,69 \%. Hal tersebut menunjukkan bahwa semakin banyak penggunaan karagenan semakin tinggi pula kadar serat kasar pada fruit leather. Peningkatan kadar serat pada fruit leather kulit buah naga disebabkan oleh konsentrasi karagenan yang ditambahkan semakin banyak. Karena karagenan adalah salah satu komponen serat dari rumput laut (Winarno, 1996).

\section{Kapasitas Antioksidan}

Hasil analisis ragam menunjukkan bahwa penambahan karagenan pada fruit leather kulit buah naga merah berpengaruh tidak nyata $(\mathrm{P}>0,05)$ terhadap kapasitas antioksidan. Nilai rata-rata kapasitas antioksidan dapat dilihat pada Tabel 2. Tabel 2 menunjukan bahwa nilai ratarata dari kapasitas antioksidan berkisar antara $0,69-0,75 \%$. Kapasitas antioksidan fruit leather 
dipengaruhi oleh kulit buah naga merah, dalam penelitian ini jumlah kulit buah naga merah yang digunakan untuk setiap perlakuan tidak ada perbedaan yaitu sebesar $100 \mathrm{~g}$, sehingga kapasitas antioksidan yang dihasilkan sama karena menggunakan jumlah ekstrak kulit buah naga yang sama. Menurut penelitian $\mathrm{Wu}$,dkk. (2006) keunggulan dari kulit buah naga yaitu kaya polifenol dan merupakan sumber antioksidan, selain itu aktivitas antioksidan pada kulit buah naga lebih besar dibandingkan aktivitas antioksidan pada buahnya, sehingga berpotensi untuk dikembangkan menjadi sumber antioksidan alami. pada penelitian ini, karagenan tidak berkontribusi terhadap kapasitas antioksidan.

\section{Total Gula}

Hasil analisis ragam menunjukkan bahwa penambahan karagenan pada fruit leather kulit buah naga merah berpengaruh tidak nyata $(\mathrm{P}>0,05)$ terhadap total gula. Nilai rata-rata total gula dapat dilihat pada Tabel 2. Tabel 2 menunjukan bahwa nilai rata-rata dari total gula berkisar antara 50,07- 54,24 \%. Dalam penelitian ini total gula fruit leather dipengaruhi oleh jumlah gula (sukrosa) yang ditambahkan pada fruit leather Kulit buah naga, jumlah gula yang digunakan untuk setiap perlakuan adalah sama yaitu sebesar 30 g. Perlakuan penambahan karagenan tidak menunjukkan perbedaan, Total gula yang tercantum pada SNI No.1718 tentang manisan kering adalah minimal $40 \%$. Maka produk fruit leather kulit buah naga yang dihasilkan pada penelitian ini yaitu berkisar 50,07- 54,24 \% sudah memenuhi SNI yang ditentukan.

\section{Uji Tensile Strength (Kuat Tarik)}

Berdasarkan hasil analisis ragam menunjukan bahwa penambahan karagenan pada fruit leather kulit buah naga merah berpengaruh sangat nyata $(\mathrm{P}<0,01)$ terhadap tensile strengthfruit leather. Nilai rata-rata tensile strength fruit leaher dapat dilihat pada Tabel 2. Tabel 2 Menunjukan bahwa nilai rata-rata tensile strength fruit leather berkisar antara 0,62 - 2,18 $\mathrm{MPa}$. Nilai rata-rata tensile strength tertinggi terdapat pada penambahan karagenan 1,2 g (P4) yaitu sebesar 2,18 MPa, sedangkan nilai rata-rata tensile strength terendah terdapat pada penambahan karagenan $0 \mathrm{~g}$ (P0) yaitu sebesar 0,62 MPa . Hal ini menunjukan semakin banyak penambahan karagenan, kuat tarik pada fruit leather semakin meningkat. Kuat tarik berhubungan dengan tekstur fruit leather yang plastis. Tekstur plastis bisa terbentuk karena karagenan merupakan gelling agent.

Kuat tarik merupakan tarikan maksimal yang dapat dicapai sebelum produk tersebut putus atau sobek. Nilai kuat tarik menunjukkan besarnya gaya yang diperlukan untuk mencapai tarikan maksimal pada setiap satuan luas produk (Krochta dan Johnston, 2002). Semakin tinggi konsentrasi karagenan yang ditambahkan, maka gaya yang dibutuhkan suatu produk untuk sobek atau putus semakin tinggi. 


\section{Evaluasi Sensoris}

Evaluasi sensoris fruit leather kulit buah naga merah dilakukan dengan uji skor warna, dan tekstur serta tingkat kesukaan (hedonik) terhadap rasa, aroma, tekstur, warna dan penerimaan keseluruhan. Nilai rata-rata hasil analisis terhadap warna, aroma, tekstur, rasa, dan penerimaan keseluruhan fruit leather kulit buah naga dapat dilihat pada Tabel 3.

Tabel 3. Nilai rata-rata uji skor dan uji hedonik terhadap warna, aroma, tekstur, rasa, dan penerimaan keseluruhan

\begin{tabular}{|c|c|c|c|c|c|c|c|}
\hline \multirow[b]{3}{*}{ Perla-kuan } & \multicolumn{7}{|c|}{ Nilai rata-rata } \\
\hline & \multicolumn{2}{|c|}{ Uji Skor } & \multicolumn{5}{|c|}{ Uji Hedonik } \\
\hline & Warna & Tekstur & Warna & Aroma & Tekstur & Rasa & $\begin{array}{l}\text { Penerimaan } \\
\text { Keseluruhan }\end{array}$ \\
\hline P0 & $4,00 \mathrm{a}$ & $2,40 \mathrm{a}$ & $5,20 \mathrm{a}$ & $4,67 \mathrm{a}$ & $4,60 \mathrm{~b}$ & $5,67 \mathrm{~b}$ & $5,20 \mathrm{a}$ \\
\hline $\mathrm{P} 1$ & $4,00 \mathrm{a}$ & $3,20 \mathrm{~b}$ & $5,40 \mathrm{a}$ & $4,73 \mathrm{a}$ & $4,87 \mathrm{~b}$ & $6,00 \mathrm{~b}$ & $5,27 \mathrm{a}$ \\
\hline $\mathrm{P} 2$ & $4,00 \mathrm{a}$ & $3,60 \mathrm{c}$ & $5,93 \mathrm{~b}$ & $4,93 \mathrm{a}$ & $6,13 \mathrm{c}$ & $5,93 \mathrm{~b}$ & $6,07 \mathrm{~b}$ \\
\hline P3 & $4,93 \mathrm{~b}$ & $4,53 \mathrm{~d}$ & $6,40 \mathrm{~b}$ & $4,87 \mathrm{a}$ & $5,33 \mathrm{~b}$ & $6,00 \mathrm{~b}$ & $5,40 \mathrm{a}$ \\
\hline P4 & $5,00 \mathrm{~b}$ & $4,67 \mathrm{~d}$ & $6,13 \mathrm{~b}$ & $4,73 \mathrm{a}$ & $3,73 \mathrm{a}$ & $5,27 \mathrm{a}$ & $5,67 \mathrm{~b}$ \\
\hline
\end{tabular}

Keterangan : Nilai rata-rata yang diikuti oleh huruf yang berbeda pada kolom sama menunjukkan perbedaan yang nyata $(\mathrm{P}<0,05)$. Uji Hedonik skala 1-7 : 1 (sangat tidak suka), 2 (tidak suka), 3 (agak tidak suka), 4 (biasa), 5 (agak suka), 6 (suka), 7 (sangat suka). Uji Skor Skala 1-5 untuk warna : 1 (coklat pudar), 2 (coklat), 3 (merah kecoklatan), 4 (merah), 5 (sangat merah). Untuk tekstur : 1(sanagt tidak kenyal), 2 (tidak kenyal), 3 (agak kenyal), 4 (kenyal), 5 (sangat kenyal).

\section{Warna}

Analisis ragam menunjukkan bahwa penambahan karagenan berpengaruh nyata $(\mathrm{P}<0,01)$ terhadap warna fruit leather baik dengan uji skor ataupun uji hedonik. Tingkat penilaian skor terhadap warna fruit leather kulit buah naga dapat dilihat pada Tabel 3. Tabel 3 menunjukan bahwa nilai rata-rata dari uji sensoris skor warna berkisar antara 4,00 (merah) sampai dengan 5,00 (sangat merah). Nilai ratarata tertinggi diperoleh pada fruit leather penambahan karagenan 1,2 g (P4) yaitu sebesar 5,00 (sangat merah) tidak berbeda dengan penambahan karagenan $0,9 \%$ (P3) dan nilai terendah pada fruit leather penambahan karagenan $0 \%(\mathrm{P} 0)$ tidak berbeda dengan $0,3 \mathrm{~g}$ (P1) dan 0,6 g (P2) yaitu sebesar 4,00 dengan kriteria merah,

Uji tingkat kesukaan ( Tabel 3) menunjukan bahwa nilai rata-rata dari uji sensoris hedonik warna berkisar antara 5,20 (agak suka) sampai dengan 6,40 (suka). Nilai rata-rata tertinggi diperoleh pada fruit leather penambahan karagenan $0,9 \mathrm{~g}(\mathrm{P} 3)$ yaitu sebesar 6,40 (suka) tidak berbeda dengan penambahan karagenan 0,6 g (P2), 1,2 g (P4) dan nilai terendah pada fruit leather penambahan karagenan 0 g (P0) yaitu sebesar 5,20 tidak 
berbeda dengan penambahan karagenan 0,3 (P1) dengan kriteria agak suka. Panelis suka pada fruit leather dengan tingkat warna sangat merah.

\section{Aroma}

Analisis ragam menunjukkan bahwa penambahan karagenan berpengaruh tidak nyata $(\mathrm{P}>0,05)$ terhadap aroma fruit leather. Tabel 3. Tabel 3 menunjukan bahwa nilai rata-rata dari uji hedonik aroma berkisar antara 4,67 (suka) sampai dengan 4,93 (suka). Hal ini dikarenakan karagenan dan kulit buah naga tidak memiliki aroma yang khas. Sehingga panelis menilai tidak ada perbedaan aroma pada setiap perlakuan.

\section{Tekstur}

$\begin{array}{rrr}\text { Analisis } & \text { ragam menunjukkan bahwa } \\ \text { penambahan karagenan berpengaruh sangat }\end{array}$ nyata $(\mathrm{P}<0,01)$ terhadap tekstur fruit leather baik dengan uji skor ataupun uji hedonik. Tingkat penilaian skor terhadap tekstur fruit leather kulit buah naga dapat dilihat pada Tabel 3. Tabel 3 menunjukan bahwa nilai rata-rata dari uji sensoris skor tekstur berkisar antara 2,40 (tidak kenyal) sampai dengan 4,67 (sangat kenyal). Nilai rata-rata tertinggi diperoleh pada fruit leather penambahan karagenan 1,2 g (P4) yaitu sebesar 4,67 dengan kriteria sangat kenyal tidak beda dengan penambahan karagenan 0,9 g (P3), dan nilai terendah pada fruit leather penambahan karagenan $0 \mathrm{~g}$ (P0) yaitu sebesar 2,40 dengan kriteria tidak kenyal. Semakin banyak penambahan karagenan dapat meningkatkan kekenyalan pada tekstur fruit leather, pada uji sensoris yang dilakukan, tekstur yang diharapkan pada fruit leather kulit buah naga ialah tekstur plastis yang tidak mudah sobek.

Tingkat penilaian hedonik terhadap tekstur fruit leather kulit buah naga dapat dilihat pada Tabel 3. Tabel 3 menunjukan bahwa nilai ratarata dari uji hedonik tekstur berkisar antara 3,73 (biasa) sampai dengan 6,13 (suka). Nilai ratarata tertinggi diperoleh pada fruit leather penambahan karagenan 0,6 g (P2) yaitu sebesar 6,13 dengan kriteria suka, nilai terendah pada fruit leather penambahan karagenan 1,2 g (P4) yaitu sebesar 3,73 (biasa), dalam hal ini panelis menilai biasa dikarenakan penambahan karagenan 1,2 g membuat tekstur fruit leather menjadi lebih kenyal dan sedikit lengket.

\section{Rasa}

Hasil analisis ragam menunjukkan bahwa penambahan karagenan pada fruit leather kulit buah naga merah berpengaruh nyata $(\mathrm{P}<0,05)$ terhadap tingkat kesukaan rasa, nilai rata-rata rasa dapat dilihat pada tabel 3 . Tabel 3 menunjukan bahwa nilai rata-rata dari rasa fruit leather 5,27 degan kriteria agak suka sampai 6,00 dengan kriteria suka. Penambahan karagenan pada fruit leather kulit buah naga merah tidak mempengaruhi rasa karena karagenan tidak memiliki rasa yang khas.sehingga rata-rata panelis menyukai rasa pada semua perlakuan.

\section{Penerimaan Keseluruhan}

Analisis ragam menunjukkan bahwa penambahan karagenan berpengaruh sangat nyata $(\mathrm{P}<0,01)$ terhadap penerimaan keseluruhan 
fruit leather. Tingkat penilaian hedonik terhadap penerimaan keseluruhan fruit leather kulit buah naga dapat dilihat pada Tabel 3. Tabel 3 menunjukan bahwa nilai rata-rata tingkat kesukaan panelis terhadap penerimaan keseluruhan fruit leather berkisar antara 5,20 (agak suka) sampai dengan 6,07 (suka). Nilai rata-rata tertinggi diperoleh pada fruit leather penambahan karagenan 0,6 g (P2) yaitu sebesar 6,07 dengan kriteria suka tidak berbeda dengan penambahan karagenan 0,9 g (P3) dan 1,2 g (P4) dan nilai terendah pada fruit leather penambahan karagenan $0 \mathrm{~g}$ (P0) yaitu sebesar 5,20 dengan kriteria agak suka. Hal ini menunjukkan bahwa fruit leather kulit buah naga dapat diterima dengan cukup baik oleh panelis.

\section{KESIMPULAN DAN SARAN}

\section{Kesimpulan}

Berdasarkan hasil penelitian yang telah dilakukan dapat diambil kesimpulan sebagai berikut:

1. Penambahan karagenan berpengaruh terhadap kadar air, serat kasar, tensile strength, tektur, warna, dan penerimaan keseluruhan.

2. Perlakuan terbaik terdapat pada perlakuan penambahan karagenan 1,2\% yaitu dengan kadar air 10,41\%, serat kasar sebesar $7,02 \%$, kapasitas antioksidan $0,74 \%$, total gula 54,24\%, tensile strength 2,19 MPa., uji skors dan hedonik warna sangat merah dan suka, tekstur kenyal dan biasa, untuk aroma dan rasa agak suka, serta penerimaan keseluruhan suka.

\section{Saran}

Berdasarkan penelitian diatas disarankan untuk melakukan penelitian lebih lanjut tentang umur simpan fuit leather kulit buah naga merah dengan penambahan karagenan sebesar 1,2\%.

\section{DAFTAR PUSTAKA}

Anonimous. 2013. Potensi tanaman buah naga. http://www.antarasumbar.com. Diakses 25 Desember 2016.

Ciptaning, N., E. Widiowati., A. Nursiwi. 2014. Pengaruh Penambahan Karagenan pada Karakteristik Fisikokimia dan Sensoris Fruit Leather Nanas (Ananas comosus L. Merr.) dan Wortel (Daucus carota). Indonesian Food Technologists. 3(4) : 122-127.

Fardiaz D. 1989. Hidrokoloid. Pusat Antar Universitas Pangan dan Gizi Institut Pertanian Bogor. Jakarta.

Hajru,Q.F. 2013.Penentuan Aktivitas Antioksidan Kulit Buah Naga Super Merah (Hylocereus costaricensis) dan Produk Olahannya Berupa Permen Jelly. Skripsi. Bandung: Fakultas Pendidikan Matematika dan Ilmu Pengetahuan Alam. Universitas Pendidikan Indonesia.

Harsojuwono, B.A., I.W. Arnata., dan G.A.K.D. Puspawati. 2011. Rancangan Percobaan. Lintas Kata, Malang.

Historiasih, R. Z. 2010. Pembuatan Fruit leather Sirsak-Rosella. Skripsi. Surabaya: Program Studi Ilmu dan. Teknologi Pangan. Fakultas Teknologi Industri. Universitas Pembangunan Nasional Veteran.

Kanner, K., S. Harel and R. Granit. 2001. Betalains - A new class of dietary cationized antioxidants. Journal of 
Agricultural and Food Chemistry. 49: 5178-5185.

Krochta, J.M and J. Mulder. 1997. Edible and Biodegradable Polymer Film. Challenges and Opportunities. Food Technol. 51 (2) : 61-74.

Kwartiningsih, E. dan L. N. S, Mulyati. 2005. Pembuatan Fruit leather dari nenas. UNS. Semarang. Ekuilibrum. Vol 4. Hal 8-12.

Murdinah. 2010. Penelitian Pemanfaatan Rumput Laut dan Fikokoloid untuk Produk Pangan dalam Rangka Peningkatan Nilai Tambah dan Diversifikasi Pangan. Balai Besar Riset Pengolahan Produk dan Bioteknologi Kelautan \& Perikanan. www.bbp4b.litbang.kkp.go.id. Diakses pada tanggal 17 September 2016.

Saati, E. A. 2009. Identifikasi Dan Uji Kualitas Pigmen Kulit Buah Naga Merah (Hylocareus costaricensis) pada Beberapa Umur simpan Dengan Perbedaan Jenis Pelarut. Jurnal Gamma . 6(1).

Saneto, B. 2010. Karakteristik Kulit Buah Naga Merah. Jurusan Teknologi Hasil Pertanian Fakultas Pertanian Universitas Widyagama Malang.
Soekarto, 1985. Penilaian Organoleptik untuk Industri Pangan dan Hasil Pertnian. Pusat Pengembangan Teknologi Pangan, IPB, Bogor.

Sudarmadji, S., B. Haryono dan Suhardi. 1997. Prosedur Analisa Bahan Makanan dan Pertanian. Liberty. Yogyakarta.

Wahyuni, R. 2011. Pemanfaatan Kulit Buah Naga Supermerah (Hylicereus Costaricensis) sebagai Sumber Antioksidan dan Pewarna Alami pada Pembuatan Jelly. Jurnal Teknologi Pangan. 2(1): 68-85.

Winarno, F. G. 1990. Teknologi Pengolahan Rumput Laut. Pustaka Sinar Harapan, Jakarta.

Wu, L. C., H. W. Hsu., Y. Chen., C. C. Chiu., and Y. I.Ho. 2006, Antioxidant and Antiproliferative Activities of Red Pitaya. Food Chemistry. 95: 319-327

Yun, L. 2001. Free Radical Scavenging Properties of Counjugated Linoic Acids. Journal of Agricultural and Food Chemistry. 49: 3452-3456. 